2. The Instrument of Accession shall be deposited with the Department of Foreign Affairs of the Republic of Indonesia.

3. With respect to any such new member Government acceding to this Agreement after it has come into force, this Agreement shall become effective in relation to that new member Government on the date of deposit of this Instrument of Accession.

4. If such an Instrument of Accession is deposited before this Agreement comes into force, it shall become effective in relation to that new member Government on the date this Agreement comes into force.

\title{
TERMS OF REFERENCE OF THE ECONOMIC AND SOCIAL COMMISSION FOR ASIA AND THE PACIFIC*
}

\section{The Economic and Social Council,}

Having considered General Assembly resolution 46 (I) of 11 December 1946, in which the General Assembly "recommends that, in order to give effective aid to the countries devastated by war, the Economic and Social Council, at its next session, give prompt and favourable consideration to the establishment of an Economic Commission for Asia and the Far East",

Having noted the report of the Working Group for Asia and the Far East of the Temporary Subcommission on Economic Reconstruction of Devastated Areas,

Establishes an Economic and Social Commission for Asia and the Pacific with terms of reference as follows:

1. The Economic and Social Commission for Asia and the Pacific, acting within the framework of the policies of the United Nations and subject to the general supervision of the Council, shall, provided that the Commission takes no action in respect of any country without the agreement of the Government of that country:

(a) Initiate and participate in measures for facilitating concerted action for the economic reconstruction and development of Asia and the Pacific, for raising the level of economic activity in Asia and the Pacific and for maintaining and strengthening the economic relations of these areas both among themselves and with other countries of the world;

\footnotetext{
* The present text includes all revisions and amendments as referred to in the Note of the UN Secretary-General of 23 June 1994, and is reproduced from the annex of that document $(\mathrm{E} / 1994 / 81)$.
} 
(b) Make or sponsor such investigations and studies of economic and technological problems and developments within territories of Asia and the Pacific as the Commission deems appropriate;

(c) Undertake or sponsor the collection, evaluation and dissemination of such economic, technological and statistical information as the Commission deems appropriate;

(d) Perform such advisory services, within the available resources of its secretariat, as the countries of the region may desire, provided that such services do not overlap with those rendered by the specialized agencies or the relevant United Nations bodies;

(e) Assist the Economic and Social Council, at its request, in discharging its functions within the region in connection with any economic problems, including problems in the field of technical assistance;

(f) In carrying out the above functions, deal, as appropriate, with the social aspects of economic development and the interrelationship of the economic and social factors.

2. The territories of Asia and the Pacific referred to in paragraph 1 shall include Afghanistan, Australia, Azerbaijan, Bangladesh, Bhutan, Brunei Darussalam, Cambodia, China, the Cook Islands, Fiji, French Polynesia, Guam, Hong Kong, India, Indonesia, Iran (Islamic Republic of), Japan, Kazakhstan, Kiribati, Korea, Kyrgyzstan, the Lao People's Democratic Republic, Macau, Malaysia, Maldives, Marshall Islands, Micronesia (Federated States of), Mongolia, Myanmar, Nauru, Nepal, New Caledonia, New Zealand, Niue, Northern Mariana Islands (Commonwealth of), Pakistan, Papua New Guinea, the Philippines, Samoa, Singapore, Solomon Islands, Sri Lanka, Tajikistan, Thailand, Tonga, the Trust Territory of the Pacific Islands, Turkmenistan, Tuvalu, Uzbekistan, Vanuatu and Viet Nam.

3. The members of the Commission shall consist of Afghanistan, Australia, Azerbaijan, Bangladesh, Bhutan, Brunei Darussalam, Cambodia, China, Democratic People's Republic of Korea, Fiji, France, India, Indonesia, Iran (Islamic Republic of), Japan, Kazakhstan, Kiribati, Kyrgyzstan, the Lao People's Democratic Republic, Malaysia, Maldives, Marshall Islands, Micronesia (Federated States of), Mongolia, Myanmar, Nauru, Nepal, the Netherlands, New Zealand, Pakistan, Papua New Guinea, the Philippines, the Republic of Korea, the Russian Federation, Samoa, Singapore, Solomon Islands, Sri Lanka, Tajikistan, Thailand, Tonga, Turkmenistan, Tuvalu, the United Kingdom of Great Britain and Northern Ireland, the United States of America, Uzbekistan, Vanuatu and Viet Nam, provided that any State in the area which may hereafter become a Member of the United Nations shall be thereupon admitted as a member of the Commission.

4. The associate members shall include the Commonwealth of the Northern Mariana Islands, the Cook Islands, French Polynesia, Guam, Hong Kong, Macau, New Caledonia, Niue, the Republic of Palau and the Territory of American Samoa.

5. Any territory, part or group of territories within the geographical scope of the Commission as defined in paragraph 2 may, on presentation of its application to the 
Commission by the member responsible for the international relations of such territory, part or group of territories, be admitted by the Commission as an associate member of the Commission. If it has become responsible for its own international relations, such territory, part or group of territories may be admitted as an associate member of the Commission on itself presenting its application to the Commission.

6. Representatives of associate members shall be entitled to participate without vote in all meetings of the Commission, whether sitting as Commission or as Committee of the Whole.

7. Representatives of associate members shall be eligible to be appointed as members of any committee, or other subordinate body, which may be set up by the Commission and shall be eligible to vote and hold office in such body.

8. The Commission is empowered to make recommendations on any matters within its competence directly to the Governments of members or associate members concerned, Governments admitted in consultative capacity, and the specialized agencies concerned. The Commission shall submit for the Council's prior consideration any of its proposals of activities that would have important effects on the economy of the world as a whole.

9. The Commission shall invite any Member of the United Nations not a member of the Commission to participate in a consultative capacity in its consideration of any matter of particular concern to that non-member.

10. The Commission shall invite representatives of specialized agencies and may invite representatives of any intergovernmental organizations to participate in a consultative capacity in its consideration of any matter of particular concern to that agency or organization following the practice of the Economic and Social Council.

11. The Commission shall make arrangements for consultation with non-governmental organizations which have been granted consultative status by the Economic and Social Council, in accordance with the principles approved by the Council for this purpose and contained in Council resolution 1296 (XLIV).

12. The Commission shall take measures to ensure that the necessary liaison is maintained with other organs of the United Nations and with the specialized agencies. The Commission shall establish appropriate liaison and cooperation with other regional economic commissions in accordance with the resolutions and directives of the Economic and Social Council and the General Assembly.

13. The Commission may, after discussion with any specialized agency functioning in the same general field, and with the approval of the Council, establish such 
subsidiary bodies as it deems appropriate, for facilitating the carrying out of its responsibilities.

14. The Commission shall adopt its own rules of procedure, including the method of selecting its Chairman.

15. The Commission shall submit to the Council a full report on its activities and plans, including those of any subsidiary bodies, once a year.

16. The administrative budget of the Commission shall be financed from the funds of the United Nations.

17. The Secretary-General of the United Nations shall appoint the staff of the Commission, which shall form part of the Secretariat of the United Nations.

18. The headquarters of the Commission shall be located at Bangkok, Thailand.

19. The Council shall, from time to time, make special reviews of the work of the Commission.

\section{JAPAN'S OFFICIAL DEVELOPMENT ASSISTANCE CHARTER*}

30 June 1992

In order to garner broader support for Japan's Official Development Assistance (ODA) through better understanding both at home and abroad and to implement it more effectively and efficiently, the Government of Japan has established the following Charter for its ODA.

\section{BASIC PHILOSOPHY}

Many people are still suffering from famine and poverty in the developing countries, which constitute a great majority among countries in the world. From a humanitarian viewpoint, the international community can ill afford to ignore this fact.

The world is now striving to build a society where freedom, human rights, democracy and other values are ensured in peace and prosperity. We must recognize

\footnotetext{
* Text from the Japanese Ministry of Foreign Affairs.
} 